\title{
ANALISIS POTENSI ASAM LEMAK OMEGA 3, OMEGA 6, DAN OMEGA 9 DARI RUMPUT LAUT (Kappaphycus alvarezii) PADA PENINGKATAN NUTRISI BALITA
}

\section{ANALYSIS OF THE POTENTIAL FATTY ACIDS OMEGA 3, OMEGA 6 AND OMEGA 9 FROM SEAWEED (Kappaphycus alvarezii) ON IMPROVING THE NUTRITION OF TODDLERS}

\author{
Nurasmi ${ }^{1)}$, Susanti ${ }^{2)}$ \\ 1.2) Program Studi Kebidanan, Fakultas Ilmu Kesehatan \\ Universitas Borneo Tarakan \\ Jalan Amal Lama Nomor 1, Tarakan \\ Email: ${ }^{1}$ asmiyuri2@gmail.com
}

\begin{abstract}
ABSTRAK
Nutrisi sangat penting dalam proses pertumbuhan dan perkembangan pada balita. Salah satu nutrisi tersebut adalah Asam lemak essensial yang diperlukan oleh janin dan bayi yang berperan utama dalam perkembangan system syaraf dan dapat meningkatkan kemampuan memori serta daya pembelajaran. Rumput laut merupakan tumbuhan laut yang berpotensi sebagai sumber pangan yang mengandung asam lemak essensial. Asam lemak omega-3, omega- 6 dan omega-9 banyak terdapat pada ikan laut, Namun, harga ikan memiliki nilai ekonomi yang lebih tinggi jika dibandingkan dengan rumput laut. Salah satu kekayaan sumber daya alam di Tarakan adalah rumput laut yang dibudidayakan oleh masyarakat Binalatung. Adanya kekayaan tersebut memiliki potensi untuk pengembangan pengelolaan rumput laut jenis Kappaphycus alvarezii. Tujuan penelitian ini untuk untuk menganalisis potensi asam lemak omega-3, omega-6 dan omega-9 dari Kappaphycus alvarezii di Kota Tarakan. Metode yang digunakan yaitu HPLC (high performance liquid chromatography). Hasil penelitian menunjukkan bahwa kandungan Kappaphycus alvarezii mengandung asam lemak omega-3 9,4 g/100 gr, asam lemak omega-6 23,7 gr/100gr dan asam lemak omega-9 9,7 gr/100gr. Kandungan tertinggi dalam kandungan Kappaphycus alvarezii adalah asam lemak omega- 6 sebesar 23,7 g/100 gr.
\end{abstract}

\section{Kata Kunci : Asam Lemak Omega-3, Omega-6, Omega-9, Kappaphycus alvarezii}

\begin{abstract}
Nutrition is very important in the process of growth and development in toddlers. One of these nutrients are fatty acid needed by the life of the fetus and the baby who was instrumental in the development of the nervous system and can improve memory and learning power. Seaweed is a potentially sea plants as food sources containing the fatty acids of life. Omega-3 fatty acids, omega- 6 and omega-9 contained in marine fish, However, the price of fish has a higher economic value compared to seaweed. One of the wealth of natural resources on Tarakan was the seaweed cultivated by the community Binalatung. The existence of such wealth have the potential for the development of the management of the seaweeds Kappaphycus alvarezii type. The purpose of this research was to analyze the potential for the omega-3 fatty acids, omega-6 and omega-9 from Kappaphycus alvarezii at Tarakan. Methods used namely HPLC (high performance liquid chromatography). The results showed that the content of Kappaphycus alvarezii contain omega-3 fatty acids $9.4 \mathrm{~g} / 100 \mathrm{~g}$ of fatty acid, omega-6 $23.7 \mathrm{gr} / 100 \mathrm{gr}$. and omega-9 fatty acids $9.7 \mathrm{grams} / 100 \mathrm{gr} .$. highest Content in Kappaphycus alvarezii is content of fatty acids Omega- 6 amounted to $23.7 \mathrm{~g} / 100 \mathrm{gr}$.
\end{abstract}

Keywords: 4.0 Learning, Google Clasroom, Google Form 


\section{PENDAHULUAN}

Anak kurang gizi mengalami hambatan pertumbuhan akibat dari kekurangnya zat gizi makro dan mikro. Kekurangan zat tersebut menyebabkan anak terinfeksi berbagai jenis penyakit. Perkembangan mental dan intelektual juga akan terhambat akibat kekurangan energi, protein dan gizi mikro. Hal tersebut mengakibatkan terhambatnya pertumbuhan sel-sel otak dan syaraf selama proses perkembangan hingga usia dua tahun. Respon daya tahan juga terpengaruhi dimana terjadi penurunan karena ketidak mampuan tubuh dalam mensintesa protein pembentuk antibody limposit-T. hal itu disebabkan oleh tidak tersedianya asam-asam amino dan mineral mikro.

Tingkat kesadaran tentang kesehatan yang rendah dalam suatu masyarakat harus di atasi dengan sumber daya yang ada di sekitarnya. Salah satu contoh adalah pencarian asupan gizi baru dari bahan non ekonomis atau mempunyai nilai ekonomis rendah. Laut Tarakan kaya akan berbagai jenis ikan dan alga (rumput laut). Pada tahun 2009, produksi rumput laut di kota Tarakan berkisar 500 ton per bulan. Masuk 2014, produksi rumput laut mengalami peningkatan yang signifikan hingga mencapai 2.000 ton per bulan. Hal ini menjadikan rumput laut satu potensi besar untuk dimanfaatkan dalam peningkatan nutrisi balita. Banyak produk rumput laut, memiliki nilai ekonomi yang rendah, namun mampu dimanfaatkan untuk mendapatkan sesuatu yang berguna seperti kandungan omega-3, omega-6 dan omega-9. Manfaat omega 3 sangat besar pengaruhnya terhadap perkembangan otak dan tubuh bayi. Beberpa hasil penelitian menunjukkan bahwa omega 3 dan 6 dapat menunjang kecerdasan otak demi terwujudnya balita pintar (Lisa, 2010). Salah satu kandungan rumput laut yang belum banyak dimanfaatkan adalah omega 3. Asam lemak omega-3 jenis lainnya yaitu jenis EPA dan linolenat berturut-turut adalah 1,43 dan $1,33 \%$ (Abirami:2016).
Beberapa faktor yang berpengaruh terhadap balita, diantaranya adalah faktor lingkungan keluarga dan kemampuan otak balita. Dalam rangka mengoptimalkan kemampuan balita, diperlukan berbagai rangsangan otak. Salah satu rangsangan untuk meningktakan kemapuan balita adalah dengan makanan yang mengandung omega 3 , omega 6 dan omega 9 (Robert:2013).

Selama masa kehamilan Sistem saraf pusat dan otak adalah organ vital yang pertama dibentuk selama masa hamil. Proses pembentukan serta pertumbuhan sel neuron otak terjadi pada minggu ke-20 hingga ke-36, dan akan disempurnakan hingga bayi berusia dua tahun. Otak membutuhkan energy lebih dari $70 \%$ dalam proses perkembangannya, energi tersebut diperoleh dari deposit zat gizi dan asam lemak esensial. Salah satunya didapatkan dari rumput laut yang memiliki potensi sebagai sumber pangan yang besar (Aslan, 1999).

\section{METODE PENELITIAN}

1. Waktu dan Tempat

Penelitian dilaksanakan pada bulan September 2018 hingga November 2018 di Laboratorium Nutrisi Ikan, Fakultas IImu Perikanan, Universitas Borneo Tarakan dan Laboratorium SIG Bogor. Pengambilan sampel dilakukan di nelayan budidaya rumput laut binalatung kota Tarakan.

2. Ekstaksi Rumput Laut

Ekstraksi rumput laut dilakukan dengan menggunakan metode maserasi atau perendaman. Proses ekstraksi rumput laut terdiri dari : 1). Pengeringan rumput laut, 2). Penghancuran hingga menjadi tepung/serbuk, 3). Serbuk Rumput Laut dimaserasi dengan menggunakan etanol 96\% (100 ml), 4). Dimaserasi selama 3 hari, 5). Evaporasi dan 6). Ekstrak kasar rumput laut.

3. Analisis Kandungan Omega 3, Omega 6 dan Omega 9

Semua peralatan penelitian sebelum digunakan terlebih dahulu disterilkan baik 
alat yang digunakan untuk ekstraksi rumput laut agar terhindar dari kontaminasi. Pengukuran kandungan senyawa omega 3, omega 6 dan omega 9 pada ikan dilakukan di laboratorium Akademi Kimia Analisis Bogor dengan menggunakan metode alat high performance liquid chromatography (HPLC). Ekstrak rumput laut sebanyak $1 \mathrm{uL}$ dari larutan diinjeksikan ke dalam HPLC,
Interval waktu penguapan dan injeksi diusahakan seminimal mungkin dan untuk menghindari proses oksidasi dari ekstraksi rumput laut yang didapatkan dan analisa kualitatif dari data kromatogram HPLC yang didapatkan.

\section{HASIL DAN PEMBAHASAN}

Hasil analisis rumput laut Kappaphycus alvarezii dapat dilihat pada Tabel berikut:

\section{Tabel 1. Kandungan Asam Lemak Omega 3, Omega 6, Omega 9

\begin{tabular}{cccc}
\hline & \multicolumn{3}{c}{ Jenis asam lemak (gr/100gr) } \\
\cline { 2 - 4 } & Omega-3 & Omega-6 & Omega-9 \\
\hline 1 & $9,4 \mathrm{gr}$ & $23,7 \mathrm{gr}$ & $9,7 \mathrm{gr}$ \\
\hline
\end{tabular}

Dari hasil diatas menunjukkan bahwa ikan nomei mengandung asam lemak omega-3 adalah 9,4 g/100 gr, asam lemak omega-6 adalah $23,7 \mathrm{gr} / 100 \mathrm{gr}$ dan asam lemak omega-9 adalah $9,7 \mathrm{gr} / 100 \mathrm{gr}$. Kandungan tertinggi adalah asam lemak omega-6. Menunjukkan bahwa rumput laut Kappaphycus alvarezii dapat dimanfaatkan masyarakat untuk meningkatkan gizi balita sebagai pengganti ikan. Ketersediaan Kappaphycus alvarezii di Kota Tarakan cukup tinggi dan telah banyak dibudidayakan oleh masyarakat binalatung, sehingga dapat dijadikan pilihan alternatif untuk masyarakat dalam pemenuhan kebutuhan asam lemak tak jenuh.

Berdasarkan penelitian Diana (2009), menyatakan bahwa rata-rata konsumsi omega 3 rata-rata1,78 gram/hari, konsumsi EPA ratarata adalah 0,11 gram/hari dan konsumsi DHA rata-rata 0,34 gram/hari pada anak usia 2-5 tahun.dan perkembangan anak pada usia 2-5 adaah $54,8 \%$.

Berdasarkan penelitian Lamid, Astuti dkk tahun 1999 mengemukakan bahwa terdapat perbedaan kadar asam lemak omega 3 (asam lemak linolenat) ,EPA, DHA dan total omega 3 berbeda secara nyata antara kelompok KEP berat dan gizi baik. Rata - rata asam lemak omega 3 (asam lemak linolenat) yang didapatakan dalam darah anak balita kelompok KEP berat jauh lebih rendah jika dibandingkan dengan kelompok gizi baik, termasuk rata-rata kadar EPA dan DHA, DHA sangat penting untuk perkembangan sel otak, minimnya kadar DHA sangat berpengaruh terhadap pertumbuhan sel otak, pada akhirnya akan mempengaruhi perkembangan psikomotor dan mental anak balita dengan KEP berat.

Menurut Georgieff (2010), zat gizi sangat berpengaruh pada struktur anatomi otak yang di bentuk dan melalui proses pertumbuhan selsel syaraf yang akan menentukan ukuran sel syaraf serta melalui proses perkembangan selsel syaraf menuju terbentuknya sel syaraf dengan komponen yang lengkap. Dalam proses pembelahan, pertumbuhan dan perkembangan sel-sel syaraf di butuhkan energi, protein yang cukup dan lemak. Zat gizi kategori makro terpenting yang dibutuhkan adalah lemak tidak jenuh gandgmaia rantai panjang.

Kekurangan asam lemak omega-3 dapat mengakibatkan gangguan syaraf. Selama masa bayi, kurangannya asupan omega-3 dapat menghambat pembentukan sel neuron sehingga proses tumbuh kembang sel otak tidak normal (Almatsier: 2006).

\section{KESIMPULAN}

Berdasarkan hasil dari uji HPLC diketahui bahwa tiap $100 \mathrm{mg} / \mathrm{g}$ Kappaphycus alvarezii mengandung omega 3 sebesar $9.7 \mathrm{mg} / \mathrm{g}$, omega 6 sebesar $23.7 \mathrm{mg} / \mathrm{g}$ dan omega 9 sebesar $9.4 \mathrm{mg} / \mathrm{g}$. 
JURNAL BORNEO SAINTEK

Volume 2, Nomor 1, April 2019

e-ISSN 2599-3313

p-ISSN 2615-434X

\section{DAFTAR PUSTAKA}

Almatsier, S., 2006. Prinsip Dasar Ilmu Gizi, edisi ke-6. Jakarta: Gramedia. Pustaka utama.

Abirami, Murugesan \& Narender Sivaswamy. 2016. Profiling of Omega 3 fatty acids from marine green algae Ulva reticulata and Caulerpa racemosa. International Journal of Phytopharmacy. Vol. 6 (2), pp. 46-50.

Aslan, LM. 1999. Budidaya Rumput Laut. Yogyakarta: Penerbit Kanisius.

Diana, Fivi melva. 2009. Hubungan Konsumsi Asam Lemak dengan Perkembangan Anak Usia 2 - 5 tahun di Kecamatan
Available online at www.jurnal.borneo.ac.id

Halaman 33-36

Nanggalo Kota Padang (Tesis) UNAND, Padang.

Diana, F.M. 2013. Omega 3 dan Kecerdasan Anak. Jurnal Kesehatan Masyarakat. Vol.7, No.2.

Georgieff M.K. 2010. Iron Deficiency and Brain Development. Elsevier. DOI: 10.1016/j.spen.2006.08.004.

Noviardi, A. 2011. Kualitas hidup manusia indonesia di peringkat ke-124 dunia http://datakesra.menkokesra.go.id com. (20 September 2013).

Robert J. Winwood. 2013. Recent developments in the commercial production of DHA and EPA rich oils from micro-algae. OCL 2013, 20(6) D604. OCL 2013, 20(6) D604. 